\title{
Pendidikan Antikorupsi Kepada Siswa Sekolah Dasar dengan Metode Storytelling
}

\author{
Naurissa Biasini ${ }^{\# 1}$, Clara Moningka ${ }^{* 2}$, Emma R Aliudin ${ }^{\# 3}$, Suci Marini*4 \\ \#Ilmu Komunikasi, Universitas Pembangunan Jaya \\ Bintaro, Tangerang Selatan \\ 1naurissa.biasini@upj.ac.id \\ 3 emma.aliudin@upj.ac.id \\ *Psikologi dan Ilmu Komunikasi, Universitas Pembangunan Jaya \\ Bintaro, Tangerang Selatan \\ ${ }^{2}$ clara.moningka@upj.ac.id \\ ${ }^{4}$ suci.marini@upj.ac.id
}

\begin{abstract}
The level of corruption in Indonesia has not decreased significantly even though there have been severe criminal penalties and prevention systems carried out. It is considered that the behavior of corruption is taken root in the mentality of the Indonesian people. Therefore, anti-corruption education needs to be provided early to reduce the possibility of someone to commit corruption when they are adults. The right education method can provide significant results in achieving educational goals to be achieved. The Community Service Team of the Communication Science and Psychology Study Program at Universitas Pembangunan Jaya held an anti-corruption education for elementary school students in collaboration with Sawah Baru Elementary School. The target of this program is elementary school students in grades 3, 4 and 5. In this anti-corruption education, the team used storytelling methods to facilitate and increase understanding in participant's mind. It turns out that this storytelling method has a large impact on the understanding of corruption in the view of elementary school students. In the future, we hope anticorruption education can be held in every school or into the education curriculum.
\end{abstract}

Keywords-anticorruption, education, storytelling

\section{PENDAHULUAN}

Masalah korupsi di Indonesia kerap menjadi berita utama dan dianggap sebagai perilaku yang telah berakar. Indonesia sendiri memiliki peringkat yang tinggi dalam korupsi. Nilai indeks persepsi korupsi Indonesia pada 2016 adalah 37. Dari rentang nilai 0-100, di mana semakin tinggi skor semakin rendah tingkat risiko korupsi. Dengan skor tersebut, Indonesia berada di peringkat ke-90 dari 176 negara yang disurvei TII (Transparency
International Indonesia). Berdasarkan data Indonesian Corruption Watch (ICW) yang dirilis Februari 2017 tercatat 482 kasus korupsi di negara ini selama 2016. Dari jumlah tersebut terdapat 1.101 orang tersangka dengan total nilai kerugian negara mencapai Rp 1,45 triliun [1]. Selain itu, data Laporan Tahunan KPK menyebutkan bahwa $78 \%$ masyarakat di Indonesia menganggap korupsi adalah hal yang umum atau sering terjadi di Indonesia, dimana dua besar pelaku korupsi menurut masyarakat adalah Anggota DPR/DPRD 
dan Kepala Daerah. Data-data tersebut menunjukkan bahwa perilaku korupsi masih marak di Indonesia.

$\begin{array}{rcrr}\text { Pada } & \text { dasarnya } & \text { berbagai upaya } \\ \text { dilakukan } & \text { untuk } & \text { mencegah }\end{array}$ memberantas korupsi. Salah satunya dengan Instruksi Presiden (Inpres) No. 10 Tahun 2016 tentang Aksi Pencegahan dan Pemberantasan Korupsi [2]. Melalui inpres ini, Presiden Jokowi mengajak jajaran di kementerian, lembaga tinggi negara, Badan Usaha Milik Negara (BUMN), dan pemerintah daerah untuk melaksanakan aksi Pemberantasan dan Pencegahan Korupsi (PPK) dengan serius dan bertanggung jawab[3]. Salah satu cara implementasi dari inpres ini adalah sistem manajemen anti penyuapan. Secara global standarisasi dilakukan melalui sertifikasi ISO 37001:2016 Anti-Bribery Management System. Standar ini berisi serangkaian tindakan yang harus dilakukan untuk mencegah, mendeteksi, dan mengatasi penyuapan.

Meskipun begitu, pada kenyataannya hal tersebut tidak membuat koruptor takut dalam melakukan tindak korupsi. Di tahun 2018, KPK menangani 178 kasus korupsi, dimana sebanyak 152 di antaranya adalah kasus penyuapan [4]. Berdasarkan situasi yang telah dijelaskan di atas, perlu adanya intervensi yang juga merupakan bagian dari revolusi mental yang dicanangkan oleh Presiden Republik Indonesia, Joko Widodo. Pendidikan antikorupsi adalah salah satu cara membentuk identitas moral yang baik untuk membentuk masyarakat yang sejahtera.

Dampak korupsi yang luas menyebabkan banyak negara di dunia mulai memikirkan bagaimana mencegah korupsi sejak usia dini. Hal ini diharapkan agar perilaku anti korupsi mengakar karena ditanamkan pada individu di keluarga dan di bangku sekolah. Pendidikan anti korupsi pada dasarnya dapat diterapkan sejak dini dimulai dari perilaku sederhana seperti mengantri, tidak mencontek, dan lain sebagainya yang pada intinya adalah pembelajaran yang penting dalam menghargai suatu proses; tidak sekadar instan. Saat ini, generasi yang lebih muda cenderung mengidentifikasi bahwa kehidupan yang baik adalah dengan gaya hidup yang mewah. Mereka juga kerap membandingkan kehidupannya dengan kehidupan orang lain di dunia maya [5]. Perbandingan sosial yang dilakukan di sosial media menyebabkan individu mengadopsi gaya hidup tersebut tanpa mempertimbangkan proses yang harus dilakukan. Pada dasarnya, keadaan ini dapat menyebabkan individu melakukan korupsi.

Banyak negara mulai melakukan program pendidikan anti korupsi sejak dini. Salah satu negara yang menerapkan pendidikan anti korupsi adalah Lithuania. Hal ini merupakan suatu bentuk kekhawatiran pemerintah Lithuania terhadap perilaku korupsi. Berdasarkan data Corruption Perception Index (CPI) tahun 2016, Lithuania berada pada ranking 38 dari 175 negara; tidak berbeda dari Indonesia. Semakin rendah CPI mengindikasikan semakin tinggi perilaku korupsi yang terjadi di negara tersebut. Sasaran dari kampanye dan pendidikan ini bukanlah sekadar menagkap koruptor, namun pencegahan korupsi sejak dini yang merupakan program nasional anti korupsi [6].

Program anti korupsi di bidang pendidikan dapat terdiri dari dua bentuk, yaitu terintegrasi dalam kurikulum; termasuk melibatkan siswa dalam kampanye anti korupsi dan program pelatihan jangka panjang untuk orang tua dan guru. Program anti korupsi yang 
terintegrasi dalam kurikulum ini dapat dilakukan dengan mengenalkan fenomena korupsi pada anak sejak dini. Di Indonesia sendiri, pendidikan anti korupsi tidak termasuk dalam sistem pendidikan dasar dan menengah, namun sudah ada program pelatihan untuk guru. sebagai sumber utama penyampaian pesan kepada siswa [7].

Program anti korupsi pada dasarnya sesuai dengan Theory of Planned Behavior yang menjelaskan bahwa probabilitas munculnya perilaku akan semakin besar bergantung pada intensi individu. Hal ini sangat tergantung dari seberapa keras usaha individu untuk melakukan perilaku tersebut [8]. Teori ini berusaha untuk memahami dan memprediksi perilaku manusia. Faktor utama dari teori ini adalah intensi individu.

Berdasarkan teori ini, perilaku manusia didasarkan oleh tiga macam pertimbangan yaitu kepercayaan terhadap konsekuensi suatu perilaku tertentu (behavioral beliefs), kepercayaan terhadap norma yang ada di lingkungan sosial (normative beliefs), dan kepercayaan bahwa individu dapat mengontrol perilakunya atau tidak (control beliefs) [9]. Pada program pendidikan anti korupsi di sekolah, sikap dapat dibentuk dengan memberikan pemahaman bahwa perilaku korupsi adalah perilaku yang merugikan diri sendiri dan orang lain. Dalam hal ini pemahaman juga menghasilkan norma subjektif (subjective norm) dan keyakinan bahwa individu akan berusaha mengontrol perilakunya. Ketiga komponen ini dapat membentuk behavioral intention.

Program pendidikan anti korupsi pada pendidikan dasar memang belum populer, namun dengan melihat hasil penelitian dan program yang sudah dilakukan di negara lain ada harapan bahwa kita dapat mengedukasi anak sejak dini untuk membentuk perilaku anti korupsi.
Perilaku korupsi yang sudah dianggap berakar dapat dikurangi. Semoga akan lebih baik di generasi yang akan datang. Program ini dilakukan pada underprivileged school dengan tujuan membekali siswa untuk memiliki integritas dan memahami bagaimana menciptakan kesejahteraan bersama. Diharapkan dengan kondisi mereka saat ini tidak menjadikan perbuatan merusak, mengambil milik orang lain dan lain-lain sebagai alasan. Pelatihan ini bersifat psikoedukasi. Hal ini sangat sesuai dengan program pemerintah yang akan dicanangkan pada tahun 2019, bahwa setiap sekolah mulai dari Sekolah Dasar sampai dengan Sekolah Menengah Atas perlu memasukkan pendidikan moral/karakter pada kurikulumnya. Selaras dengan program pemerintah tersebut, pengabdian masyarakat ini bertujuan melakukan edukasi pada siswa untuk mendukung terlaksananya program tersebut di sekolah; khususnya sekolah underprivileged.

Storytelling dipilih sebagai metode untuk menyampaikan pendidikan antikorupsi kepada siswa sekolah dasar dikarenakan metode ini dianggap dekat dengan anak-anak dan mudah dipahami. White [10]menyatakan bahwa orang tertarik dengan cerita karena berbagai alasan, yaitu hiburan, membantu mengatur pikiran, mempengaruhi emosi, atau menginstruksikan kita dalam bagaimana caranya hidup dan berperilaku.

Berdasarkan permasalahan di atas, maka terdapat dua aspek yang perlu dirumuskan pada materi yang akan disampaikan pada Pendidikan Antikorupsi pada Siswa Sekolah Dasar yaitu:

a. Bagaimana metode yang efektif dalam memberikan pendidikan antikorupsi kepada siswa sekolah dasar?

b. Bagaimana mengukur pemahaman siswa sekolah dasar terhadap materi pendidikan antikorupsi? 
Melalui kegiatan storytelling yang memuat kedua aspek di atas makan diharapkan akan meningkatkan pengetahuan dan membentuk sikap antikorupsi pada siswa sekolah dasar.

\section{METODE PELAKSANAAN}

Kegiatan pendidikan antikorupsi merupakan kegiatan pengabdian masyarakat yang ditujukan terutama untuk siswa sekolah dasar. Dalam kegiatan kali ini, terdapat 106 orang peserta didik dari SDN Sawah Baru kelas 3. Berikut adalah tahapan pelaksanaan kegiatan:

Pertama, tim pengabdian masyarakat berkoordinasi dengan pihak sekolah yaitu SDN Sawah Baru untuk berdiskusi mengenai pelaksanaan pendidikan antikorupsi. Berdasarkan hasil diskusi, SDN Sawah Baru memang belum memiliki pendidikan yang berkaitan dengan antikorupsi kepada pada siswa, karena itu pihak SDN Sawah Baru setuju untuk bekerja sama dalam kegiatan pendidikan antikorupsi. Kedua, berdasarkan hasil wawancara tersebut, tim mulai menyusun rancangan kegiatan pengabdian masyarakat pendidikan antikorupsi.

Dalam tahap ketiga, tim melakukan proses pre-test untuk mengetahui dan mengukur tingkat pemahaman siswa SDN Sawah Baru tentang korupsi. Keempat, penyelenggaraan pendidikan antikorupsi dengan metode storytelling. Kelima, melakukan tahapan evaluasi dengan melakukan proses post-test dengan memberikan pertanyaan kepada para peserta untuk mengukur pemahaman tentang antikorupsi setelah dilakukan proses storytelling. Kemudian evaluasi juga dilakukan dengan cara memberikan pertanyaan berkaitan dengan proses storytelling yang telah dilakukan.

\section{GAMBARAN HASIL PENGABDIAN MASYARAKAT}

Program Pengabdian Masyarakat Pendidikan Antikorupsi telah berlangsung selama 6 (enam) bulan dalam rentang waktu Januari-Juni 2019 telah mencapai hasil yang sesuai dengan perencanaan pengabdian masyarakat yang telah disusun. Adapun kegiatan yang dilakukan oleh tim pelaksana kegiatan meliputi kegiatan rapat koordinasi dengan pihak SDN Sawah Baru, pelaksanaan, hingga evaluasi.

\section{A. Persiapan Materi}

Di tahapan ini, tim pengabdian masyarakat menyusun materi yang akan disampaikan dalam kegiatan pendidikan antikorupsi. Materi yang disampaikan berbentuk penjelasan mengenai korupsi dan jenis-jenis korupsi yang sering terjadi di masyarakat. Selanjutnya tim menyusun cerita yang akan disampaikan dalam kegiatan storytellingmengenai antikorupsi. Terdapat lima cerita yang disusun dengan bentuk cerita seperti dongeng yang berkaitan dengan jenis-jenis korupsi yang sering terjadi di masyarakat, yaitu:

1. korupsi waktu

2. korupsi tanggung jawab

3. korupsi uang

4. korupsi barang

5. korupsi fasilitas umum

Setelah itu tim membuat flash card berisi cerita yang akan disampaikan untuk mempermudah proses storytelling. Flash card tersebut juga akan digunakan untuk memudahkan peserta untuk lebih memahami cerita yang disampaikan karena dapat dibaca ulang saat kegiatan pendidikan antikorupsi dijalankan ataupun dapat dijadikan alat bantu permainan. 

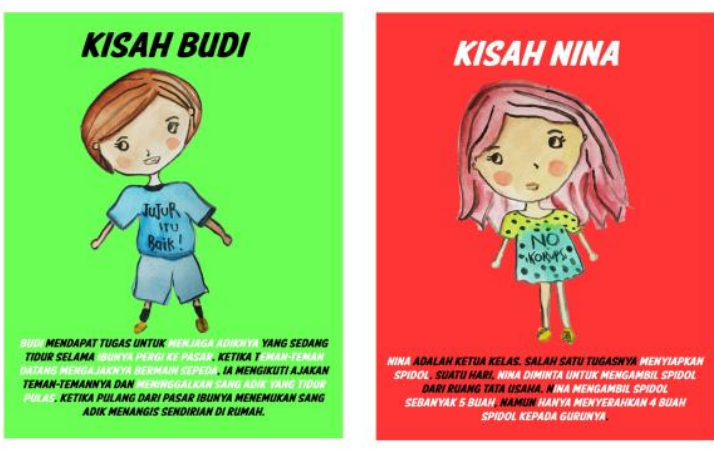

Gambar 1.Contoh flash card yang dibuat oleh tim

Flash card dicetak berwarna seukuran kertas A5 untuk dapat dibagikan dan diperlihatkan dengan mudah kepada para peserta.

\section{B. Kegiatan Pretest}

Dalam tahapan ini, tim terlebih dahulu memulai kegiatan dengan memberikan pertanyaan sederhana kepada para peserta mengenai korupsi dan jenisjenis korupsi peserta untuk mengukur pemahaman sebelum dan setelah proses pendidikan dilakukan. Poin pertanyaan yang diberikan yaitu:

1. Apakah kamu mengetahui arti dari korupsi?

2. Apakah kamu mengetahui apa yang dimaksud dengan korupsi waktu?

3. Apakah kamu mengetahui apa yang dimaksud dengan korupsi tanggung jawab?

4. Apakah kamu mengetahui apa yang dimaksud dengan korupsi uang?

5. Apakah kamu mengetahui apa yang dimaksud dengan korupsi barang?

6. Apakah kamu mengetahui apa yang dimaksud dengan korupsi fasilitas umum?
Daftar pertanyaan dan hasil jawaban tergambar dalam tabel di bawah ini:

TABEL I

PERTANYAAN DAN JAWABAN PRETEST

\begin{tabular}{|c|c|c|c|c|}
\hline No & Pertanyaan & $\mathrm{Ya}$ & Tidak & $\begin{array}{c}\text { Persentase } \\
\text { Pemaham- } \\
\text { an }\end{array}$ \\
\hline 1 & $\begin{array}{l}\text { Apakah kamu } \\
\text { mengetahui arti } \\
\text { dari korupsi? }\end{array}$ & 5 & 101 & 4.72 \\
\hline 2 & $\begin{array}{l}\text { Apakah kamu } \\
\text { mengetahui apa } \\
\text { yang dimaksud } \\
\text { dengan korupsi } \\
\text { waktu? }\end{array}$ & 0 & 106 & 0.00 \\
\hline 3 & $\begin{array}{l}\text { Apakah kamu } \\
\text { mengetahui apa } \\
\text { yang dimaksud } \\
\text { dengan korupsi } \\
\text { tanggung jawab? }\end{array}$ & 1 & 105 & 0.94 \\
\hline 4 & $\begin{array}{l}\text { Apakah kamu } \\
\text { mengetahui apa } \\
\text { yang dimaksud } \\
\text { dengan korupsi } \\
\text { uang? }\end{array}$ & 5 & 101 & 4.72 \\
\hline 5 & $\begin{array}{l}\text { Apakah kamu } \\
\text { mengetahui apa } \\
\text { yang dimaksud } \\
\text { dengan korupsi } \\
\text { barang? }\end{array}$ & 5 & 101 & 4.72 \\
\hline 6 & $\begin{array}{l}\text { Apakah kamu } \\
\text { mengetahui apa } \\
\text { yang dimaksud } \\
\text { dengan korupsi } \\
\text { fasilitas umum? }\end{array}$ & 1 & 105 & 0.94 \\
\hline
\end{tabular}

Berdasarkan Tabel 1 di atas, dapat dilihat bahwa hampir keseluruhan peserta kegiatan pengabdian masyarakat tidak mengetahui arti dari korupsi. Karena itu mereka pun tidak memahami atau mengetahui apa saja jenis korupsi yang sering terjadi di masyarakat seperti korupsi waktu, korupsi uang, korupsi tanggung jawab, korupsi barang, dan korupsi fasilitas umum. 


\section{Pemberian Materi dan Storytelling}

Selesai diberikan pertanyaan pretest, para peserta yang terbagi dalam tiga kelas, mendapatkan materi pendidikan mengenai apa itu korupsi dan jenis-jenis korupsi yang sering terjadi di masyarakat.

Setelah diberikan materi, tim kemudian menyampaikan cerita sederhana kepada para peserta mengenai korupsi, dengan tokoh Budi dan Nina sebagai pemeran utama dalam cerita tersebut. Karakter Budi dan Nina sengaja dibuat seusia dengan para peserta agar munculnya kedekatan dengan para peserta. Dalam cerita yang disampaikan, Budi dan Nina merupakan seorang siswa sekolah dasar yang sering mendapatkan kepercayaan dari orang-orang sekitarnya. Namun sayangnya Budi dan Nina sering memanfaatkan kepercayaan yang diberikan orang lain untuk kepentingannya sendiri.

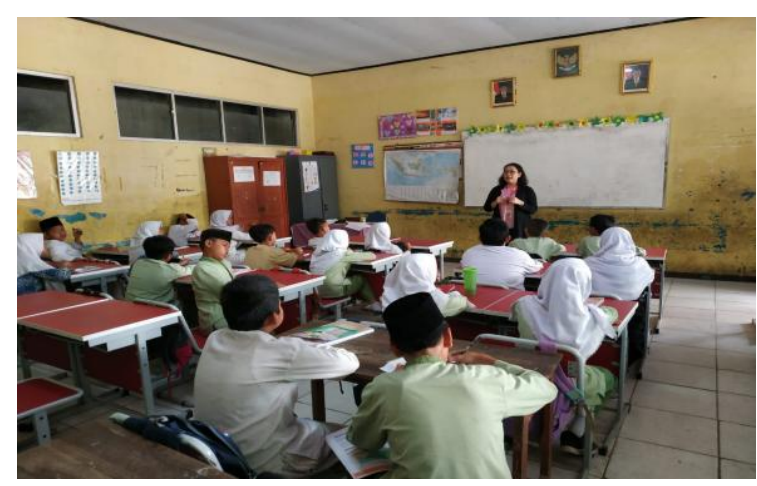

Gambar 2.Salah satu tim sedang memberikan materi pendidikan antikorupsi kepada para peserta di salah satu ruang kelas

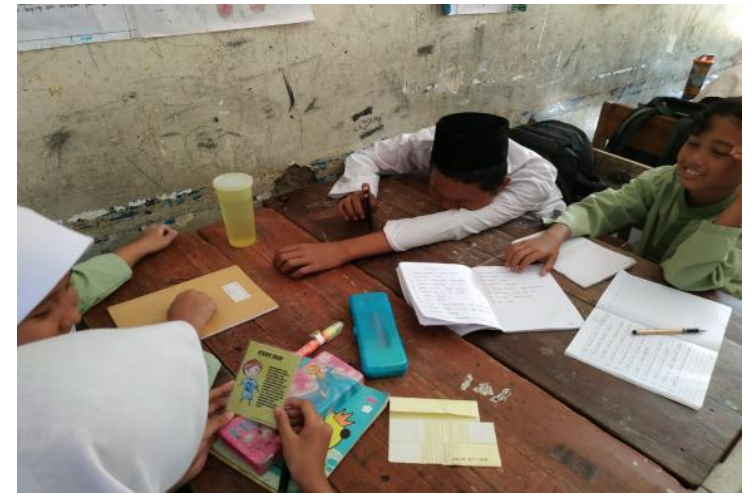

Gambar 3.Salah satu kelompok peserta sedang membaca dan berdiskusi mengenai kisah Budi dari flash card.

Setelah selesai menceritakan tentang kisah Budi dan memberikan waktu kepada para peserta untuk kembali membaca kisah tentang Budi lewat flash card yang dibagikan ke kelompok-kelompok kecil. Saat para peserta diberikan waktu untuk membaca flash card, tim berkeliling ke setiap kelompok-kelompok untuk memastikan semua peserta membaca dan paham dengan cerita yang disampaikan.

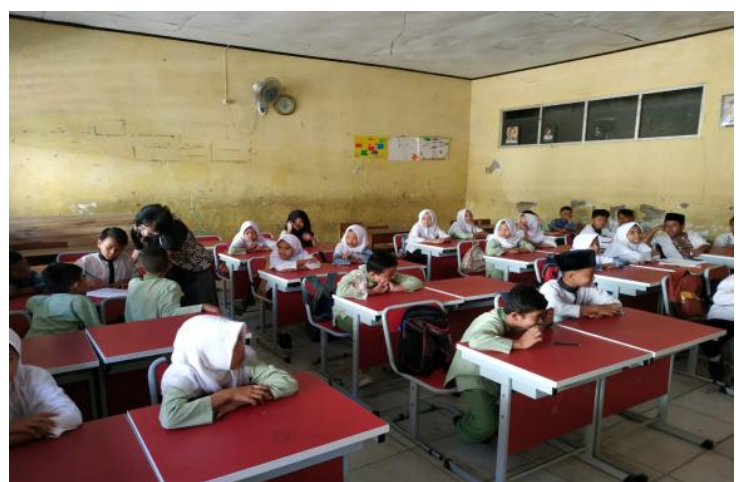

Gambar 4.Salah satu tim pengabdian masyarakat memberikan pendampingan kepada peserta untuk memahami cerita dalam flash card.

\section{Post Test}

Setelah selesai proses pemberian materi dan storytelling, Tim kemudian kembali menanyakan pemahaman mengenai korupsi kepada para peserta yang hadir untuk mengukur pemahaman tentang 
korupsi setelah selesai diberikan pendidikan antikorupsi. Pertanyaan dan hasil jawaban post test terdapat di dalam Tabel II di bawah ini:

\section{TABEL III}

PERTANYAAN DAN JAWABAN POST TEST

\begin{tabular}{|c|c|c|c|c|}
\hline No & Pertanyaan & Ya & Tidak & $\begin{array}{c}\text { Persentase } \\
\text { Pemaham- } \\
\text { an }\end{array}$ \\
\hline 1 & $\begin{array}{l}\text { Apakah kamu } \\
\text { mengetahui } \\
\text { arti dari } \\
\text { korupsi? }\end{array}$ & 106 & 0 & 100.00 \\
\hline 2 & $\begin{array}{l}\text { Apakah kamu } \\
\text { mengetahui } \\
\text { apa yang } \\
\text { dimaksud } \\
\text { dengan } \\
\text { korupsi } \\
\text { waktu? }\end{array}$ & 95 & 11 & 89.62 \\
\hline 3 & $\begin{array}{l}\text { Apakah kamu } \\
\text { mengetahui } \\
\text { apa yang } \\
\text { dimaksud } \\
\text { dengan } \\
\text { korupsi } \\
\text { tanggung } \\
\text { jawab? }\end{array}$ & 91 & 15 & 85.85 \\
\hline 4 & $\begin{array}{l}\text { Apakah kamu } \\
\text { mengetahui } \\
\text { apa yang } \\
\text { dimaksud } \\
\text { dengan } \\
\text { korupsi uang? }\end{array}$ & 100 & 6 & 94.34 \\
\hline 5 & $\begin{array}{l}\text { Apakah kamu } \\
\text { mengetahui } \\
\text { apa yang } \\
\text { dimaksud } \\
\text { dengan } \\
\text { korupsi } \\
\text { barang? }\end{array}$ & 98 & 8 & 92.45 \\
\hline 6 & $\begin{array}{l}\text { Apakah kamu } \\
\text { mengetahui } \\
\text { apa yang } \\
\text { dimaksud } \\
\text { dengan } \\
\text { korupsi } \\
\text { fasilitas } \\
\text { umum? }\end{array}$ & 88 & 18 & 84.02 \\
\hline
\end{tabular}

Dari data yang disajikan dalam Tabel 2, dapat dilihat perubahan yang signifikan terhadap pemahaman para peserta mengenai korupsi. Dari item pertanyaan nomor 1 mengenai arti korupsi meningkat dari $4.72 \%$ menjadi $100 \%$. Kemudian dari item pertanyaan nomor 2 mengenai korupsi waktu, hasil pemahaman meningkat dari $0 \%$ menjadi $100 \%$. Sedangkan dari item pertanyaan nomor 3, meningkat dari $0.94 \%$ menjadi $85.85 \%$. Kemudian dari item pertanyaan nomor 4 mengenai korupsi uang, terjadi peningkatan dari $4.72 \%$ menjadi $94.34 \%$. Untuk item pertanyaan nomor 5 mengenai korupsi barang terjadi peningkatan dari $4.72 \%$ menjadi $92.45 \%$. Terakhir untuk item pertanyaan nomor 6 mengenai korupsi fasilitas umum, terjadi peningkatan dari $0.94 \%$ menjadi $84.02 \%$.

Perbedaan tingkat pemahaman para peserta kegiatan pengabdian masyarakat antikorupsi tergambar dalam grafik batang berikut ini:

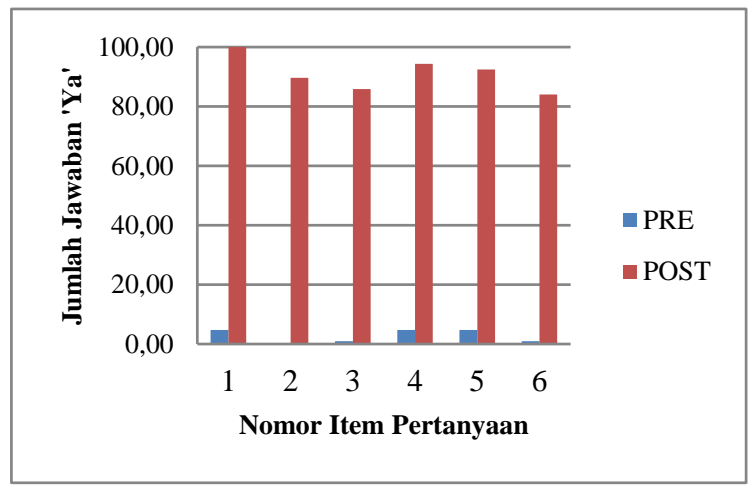

Gambar 5.Grafik batang perbandingan persentase pemahaman siswa dari proses pretest dan post test. Batang biru menunjukkan hasil pretest sendangkan batang merah menunjukkan hasil post test.

Hasil dari proses tersebut menunjukkan bahwa penggunaan metode storytelling dalam menyampaikan materi pendidikan mengenai antikorupsi memiliki tingkat keberhasilan yang tinggi. Hal ini dikarenakan pada saat penyampaian materi, terlihat antusiasme para peserta dalam mendengarkan cerita yang disampaikan. Kemudian hal ini meningkatkan tingkat pemahaman setiap peserta mengenai apa itu korupsi hingga jenis-jenis korupsi yang biasa terjadi di masyarakat. 
Selain itu, untuk menguji pemahaman masing-masing peserta, tim pengabdian masyarakat dibantu oleh mahasiswa berkeliling untuk menanyakan satu per satu mengenai korupsi dan jenisnya dan memastikan jawaban yang diberikan memang menunjukkan pemahaman, bukan sekedar menjawab 'ya' atau 'paham' saja. Hal ini dapat diketahui dengan meminta peserta untuk menjelaskan kembali seperti apa bentuk korupsi yang sudah dipelajari dan memberikan contoh kasus ringan lainnya dan meminta mereka menebak jenis korupsi yang disampaikan dalam cerita.

Tim juga memberikan beberapa pertanyaan lain kepada peserta untuk mengukur pemahaman mereka terhadap cerita yang disampaikan. Hal ini dilakukan untuk semakin memperkuat keyakinan terhadap pemahaman setiap peserta tentang korupsi, jenis korupsi, hingga bagaimana korupsi sebagai sebuah perilaku yang tidak boleh ditiru. Tabel III berikut menunjukkan daftar pertanyaan dan hasil jawaban dari pertanyaan tambahan yang diajukan, yaitu:

TABEL IIIII

DAFTAR DAN HASIL JAWABAN PERTANYAAN TAMBAHAN

\begin{tabular}{|c|l|c|c|c|}
\hline No & Pertanyaan & Ya & Tidak & $\begin{array}{c}\text { Persen- } \\
\text { Tase }\end{array}$ \\
\hline 1 & $\begin{array}{l}\text { Apakah kamu } \\
\text { paham dengan } \\
\text { cerita yang } \\
\text { disampaikan? }\end{array}$ & 106 & 0 & 100.00 \\
\hline $\begin{array}{l}\text { Apakah kamu } \\
\text { paham bahwa } \\
\text { perilaku yang } \\
\text { dilakukan oleh } \\
\text { tokoh dalam } \\
\text { cerita dapat } \\
\text { merugikan orang } \\
\text { lain? }\end{array}$ & 100 & 6 & 94.34 \\
\hline 3 & $\begin{array}{l}\text { Apakah kamu } \\
\text { paham bahwa } \\
\text { perilaku yang } \\
\text { dilakukan oleh } \\
\text { tokoh dalam } \\
\text { cerita merupakan } \\
\text { bentuk korupsi? }\end{array}$ & 95 & 11 & 89.62 \\
\hline
\end{tabular}

\begin{tabular}{|c|l|c|c|c|}
\hline 4 & $\begin{array}{l}\text { Apakah kamu } \\
\text { paham bahwa } \\
\text { perilaku yang } \\
\text { dilakukan oleh } \\
\text { tokoh dalam } \\
\text { cerita merupakan } \\
\text { perilaku buruk? }\end{array}$ & 100 & 6 & 94.34 \\
\hline 5 & $\begin{array}{l}\text { Apakah kamu } \\
\text { paham bahwa } \\
\text { perilaku yang } \\
\text { dilakukan oleh } \\
\text { tokoh dalam } \\
\text { cerita tidak boleh } \\
\text { ditiru? }\end{array}$ & 100 & 6 & 94.34 \\
\hline
\end{tabular}

Dari data Tabel III di atas, dapat dilihat nilai persentase pemahaman terhadap cerita yang disampaikan oleh tim pengabdian masyarakat. Sebesar 100\% peserta menyatakan bahwa mereka paham dengan cerita yang disampaikan. Kemudian sebesar $94.34 \%$ paham bahwa perilaku yang dilakukan oleh tokoh Budi dalam cerita dapat merugikan orang lain.

Selanjutnya Tabel III juga menunjukkan bahwa sebesar $89.62 \%$ peserta menyatakan bahwa perilaku yang dilakukan oleh tokoh dalam cerita merupakan bentuk korupsi, baik korupsi uang, waktu, tanggung jawab, barang, maupun korupsi fasilitas umum. Kemudian sebanyak $94.34 \%$ peserta memahami bahwa perilaku yang ditunjukkan oleh tokoh dalam cerita merupakan perilaku buruk dan tidak boleh ditiru.

\section{KESIMPULAN}

Tingginya tingkat korupsi di Indonesia menunjukkan angka yang sangat memprihatinkan. Korupsi nampaknya sudah menjadi sebuah kebiasaan atau budaya yang mengakar di masyarakat. Hukuman yang berat hingga program pencegahan pun nampaknya tidak memberikan rasa jera atau rasa takut untuk melakukan korupsi. 
Karena itulah diperlukan pendekatan yang berbeda untuk menanggulangi masalah korupsi. Penanaman tentang bahaya dan sikap antikorupsi perlu dimulai sejak dini dan masuk dalam proses pendidikan masyarakat terutama untuk siswa sekolah dasar, dimana pada saat tersebut merupakan masa-masa penting pembentukan mental dan sikap seseorang.

Proses penyampaian materi yang menggunaka metode storytelling ternyata memberikan hasil yang signifikan dalam memberikan pemahaman kepada para peserta yaitu siswa sekolah dasar SDN Sawah Baru. Karena itu metode ini dapat dianggap layak untuk digunakan untuk menyampaikan pendidikan mengenai edukasi antikorupsi.

Hasil pretest dan post test menunjukkan peningkatan pemahaman yang signifikan mengenai korupsi dan jenis-jenis korupsi yang sering terjadi setelah dilakukan pendidikan antikorupsi dengan metode storytelling. Selain itu para peserta pun memahami bahwa korupsi dapat merugikan orang lain, merupakan perilaku yang buruk dan tidak boleh ditiru.

Hal ini menunjukkan bahwa pendidikan antikorupsi penting dan layak untuk diberikan kepada siswa sekolah dasar dan disampaikan dengan metode yang tepat. Ditambah lagi usia sekolah dasar merupakan usia pembentukan mental dan sikap seseorang. Diharapkan jika mental antikorupsi sudah terbentuk sejak dini, akan dapat mengurangi perilaku korupsi masyarakat Indonesia di masa yang akan datang.

Hasil pengabdian masyarakat ini diharapkan juga dapat memberikan masukan kepada pemerintah atau pihak sekolah untuk memasukkan pendidikan anti korupsi menjadi bagian dalam kurikulum sekolah.
Ucapan Terima Kasih

Para penulis mengucapkan terima kasih yang sedalam-dalamnya atas dukungan dari berbagai pihak yang mendukung penelitian ini yaitu Universitas Pembangunan Jaya, LPPM UPJ, Kepala Sekolah dan Para Guru SDN Sawah Baru, Siswa/i SDN Sawah Baru, dan mahasiswa/i Universitas Pembangunan Jaya yang mendampingi saat proses pengabdian masyarakat.

\section{DAFTAR PUSTAKA}

[1] M Gewati. (2017, September)

Kompas. [Online].

http://nasional.kompas.com/read/2017/ 09/12/14170551/bunuh-diri-

kemiskinan-dan-korupsi-di-indonesia

[2] Joko Widodo. (2016, Januari) LKPP. [Online]. https://siulp.lkpp.go.id/uploads/posts/2 017/01/19/(inpres-no.-10-tahun-2016)Inpres\%20PPK\%202016\%20dan\%202 017\%20(1).pdf

[3] R Armenia. (2015, Mei) CNN Indonesia. [Online].

https://www.cnnindonesia.com/nasion al/20150526152751-12-55785/jokowiluncurkan-inpres-pencegahan-danpemberantasan-korupsi/

[4] KPK. (2018, Desember) KPK. [Online]. https://www.kpk.go.id/images/Integrit $\mathrm{o} /$ LaporanTahunanKPK/LaporanTahunan-KPK-2018-.pdf

[5] Clara Moningka,. Hershey: IGI Global, 2017. 
[6] Ministry of Education and Science Republic of Lithuania, Anti-corruption education at school: Methodical material for general and higher education schools. Virnius: Garnelis Publishing, 2006.

[7] KPK. (2017, September) KPK.

[Online]. http://nasional.kompas.com/read/2017/ 09/12/14170551/bunuh-dirikemiskinan-dan-korupsi-di-indonesia

[8] Icek Ajzen, The Theory of Planned Behavior. Organizational Behavior and Human Decision Process, 2nd ed., 2005.

[9] S Bamberg, I Ajzen, and P Schmidt, "Choice of travel mode in the theory of planned behavior: The roles of past behavior, habit, and reasoned action. Basic and applied social psychology," pp. 175-187, 2003.

[10] Michael White. (2002) Massey.

[Online]. http://www.massey.ac.nz/ alock/virtua 1/white.htm 